\title{
Antitumor Activity of Low-Dimensional Alumina Structures
}

\author{
M. S. Korovin ${ }^{1, a)}$ and A. N. Fomenko ${ }^{1, b)}$ \\ ${ }^{1}$ National Research Tomsk Polytechnic University, Lenin Avenue 30, Tomsk, 634050 Russia \\ ${ }^{a)}$ Corresponding author: msk@ispms.tsc.ru \\ b)alserova@ispms.tsc.ru
}

\begin{abstract}
Nano-dimensional materials have recently attracted much attention with respect to their potential role in medicine. Physical mechanisms of interaction of nanoparticles with tumor cells will help to develop new methods for cancer disease treatment. Based on aluminum oxide phases, positively charged low-dimensional structures have different shape: agglomerates of nanosheets, nameplates, cone-shaped nanoaggregates were synthesized with the help of aluminum nanoparticles. The cytotoxicity effect of these low-dimensional structures on A549, HeLa, MDA, PyMT tumor cells was studied. It was shown that agglomerates of nanosheets were more toxic for investigating cell lines. Agglomerates of nanosheets had a medium toxic effect at a concentration of $10 \mathrm{mg} / \mathrm{ml}$ while nameplates and cone-shaped nanoaggregates were nontoxic. The toxic effect of agglomerates of nanosheets correlates with their shape, mainly the presence of multiple edges.
\end{abstract}

\section{INTRODUCTION}

In recent years, metal oxide nanoparticles have attracted much attention with respect to their potential role in different medical applications. Some research has been devoted to developing and investigating the hybrid systems made of nanomaterials and biological cells and also using nanomaterials for the targeted cell therapy $[1,2]$.

The unique features of nanoparticles, such as high surface energy, stable sorption of biomolecules, change of physico-chemical properties under the influence of physical fields, the small sizes comparable to biomolecules, presence of magnetic properties, biocompatibility, open new prospects for application of nanotechnology-based drugs in therapy of various diseases, including cancer treatment $[3,4]$.

Successful application of nanoparticles requires clear understanding of the physical factors that define nanomaterials cytotoxicity. Being taken up by the cells, nanoparticles can interact with cell organelles, proteins, nucleic acids; they can be involved in the processing of the intracellular signaling and proliferation [5] and can potentially cause alterations of these processes [6]. Nowadays, as manufacturing and biomedical application of nanomaterials grow up, more and more concerns as regards their potential toxicity also arise.

One of such perspective materials, nano-dimensional aluminum oxide, can be produced by electrical explosion [7-10] and oxidation with water [11-14]. The prospects of its application are generally defined by the low cytotoxicity declared, simple synthesis and a variety of structural forms. Aluminum oxide nanoparticles due to their high sorption ability can serve as an anti-gene depot; they also induce nonspecific phagocytosis and can be used in vector vaccines as adjuvants [15]. Composite aluminum nanoparticles with porous structure of nanopetal pseudoboehmite produced by electrical explosion [16] with copper-containing inclusions inside [17] exhibit high antimicrobial activity. Alumina nanofibres are used in filtration processes for separation of the protein molecules [18], take part in the processes of adsorption and degradation of the TNF- $\alpha$ molecules (tumor necrosis factor) which are widely expressed in response to infection, or bacterial endotoxins uptake [19]. Low cytotoxicity of the aluminum oxide is confirmed by various studies. No significant effect on cell phagocytosis was observed with $\mathrm{Al}_{2} \mathrm{O}_{3}$ nanoparticles (alveolar macrophages of NR8383) [20]. Results [21] show the ability of aluminum oxide nanoparticles to penetrate through the membranes of L929 and BJ cells. Despite this, there was no significant increase in apoptosis or decrease in cell viability observed, suggesting that aluminum oxide nanoparticles in the tested range of concentrations has no cytotoxic effects on the selected mammalian cells. 
In a number of publications the cytotoxic effect of aluminum oxide nanoparticles and other nanomaterials is compared. For example, it is shown in [22] that toxicity of $\mathrm{Al}_{2} \mathrm{O}_{3}$ nanoparticles on $\mathrm{A} 549$ cells was totally lower than nanotubes and nanostructured $\mathrm{TiO} 2$ toxicity.

Results [23] show that four types of metal oxide nanoparticles $\left(\mathrm{ZnO}, \mathrm{TiO}_{2}, \mathrm{SiO}_{2}, \mathrm{Al}_{2} \mathrm{O}_{3}\right)$ lead to mitochondrial dysfunction, morphological changes and apoptosis of the HFL1 fibroblast cells at the concentration range of 0.25 $1.50 \mathrm{mg} / \mathrm{ml}$. Toxic effect was increased depending on the dose. The most toxic was $\mathrm{ZnO}$, toxicity of the other oxides decreased in a descending order $\mathrm{TiO}_{2}>\mathrm{SiO}_{2}>\mathrm{Al}_{2} \mathrm{O}_{3}$.

Comparison study of $\mathrm{Al}_{2} \mathrm{O}_{3}, \mathrm{CeO}_{2}, \mathrm{TiO}_{2}$ and $\mathrm{ZnO}$ nanoparticles toxicity to $\mathrm{A} 549$ carcinoma cells and normal L-132 cells has been also performed [24]. Among the four types of nanoparticles tested, $\mathrm{ZnO}$ exhibited the highest cytotoxicity in terms of cell proliferation, cell viability, membrane integrity and colony formation in both cell lines. $\mathrm{Al}_{2} \mathrm{O}_{3}$ showed less adverse effects, even after long exposure time.

However, according to data [25] aluminum oxide nanoparticles showed higher toxicity, as compared to $\mathrm{TiO}_{2}$ nanoparticles. Cytotoxicity studies of 13 and $22 \mathrm{~nm}$ aluminum oxide nanoparticles exposure on the human bronchoalveolar carcinoma-derived cells (A549) are presented. $\mathrm{CeO}_{2}$ nanoparticles $(20 \mathrm{~nm})$ and $\mathrm{TiO}_{2}(40 \mathrm{~nm})$ having high and low cytotoxicity respectively were used as control. After exposure to both $\mathrm{Al}_{2} \mathrm{O}_{3}$ nanoparticles for 24 hours at 10 and $25 \mu \mathrm{g} / \mathrm{ml}$ concentrations, cell viability significantly decreased as compared to control. At the same time $\mathrm{Al}_{2} \mathrm{O}_{3}$ nanoparticles were more toxic than $\mathrm{TiO}_{2}$ nanoparticles, but less than $\mathrm{CeO}_{2}$ nanoparticles $\left(\mathrm{TiO} \mathrm{O}_{2}<\right.$ $\mathrm{Al}_{2} \mathrm{O}_{3}<\mathrm{CeO}_{2}$ ). Using potential-sensitive fluorescent probe DiBAC4(3) membrane potential change in A549 cells caused by $\mathrm{Al}_{2} \mathrm{O}_{3}$ nanoparticles was observed.

The conclusion [24] is supported by [26]. According to these data, the cytotoxicity of $\mathrm{Al}_{2} \mathrm{O}_{3}$ particles (500$700 \mathrm{~nm}$ in diameter) to fibroblast cells is higher than that of $\mathrm{TiO}_{2}$ nanoparticles $(130-180 \mathrm{~nm})$. It is shown that an increase in the size of nanoparticles raises their cytotoxicity. As for nanoparticles shape, there is also a considerable enhancement of their cytotoxic properties with the increase in the number of edges of the dendritic particle.

Research results [27] have shown show that $\mathrm{Al}_{2} \mathrm{O}_{3}$ nanoparticles with a size of $23 \mathrm{~nm}$ can be toxic either for normal, or cancer cell lines. After exposure on VERO, HEP 2, MDA MB 231 and A549 cell lines, cell proliferation rate was decreased as concentration raised from $2 \mu \mathrm{g} / \mathrm{ml}$ to $500 \mu \mathrm{g} / \mathrm{ml}$. At $\mathrm{IC}_{50}$ nanoparticles concentration in cell samples morphological changes in cell structure were found.

The authors [28] have shown that aluminum oxide nanoparticles reduce viability of the human brain microvascular endothelial cells (HBMEC) and alter mitochondrial functions.

The toxic effect caused by oxide nanoparticles depends on their size: high toxicity is correlated with the small particles [29]. The toxicity of nanoparticles also depends on the size of the agglomerates which form primary nanoparticles [30]. Small nanoparticles $(10 \mathrm{~nm})$ combining to agglomerates show less toxicity than big-sized $(50 \mathrm{~nm})$ nanoparticles.

Considering the data published it is possible to note that conclusions about the toxicity degree of aluminum oxide nanoparticle in some studies are contradictory. There are various opinions about potential cytotoxicity of aluminum oxide nanostructures presented. The main findings from this literature are the following. Aluminum oxide nanoparticles are not well characterized by their effect on biological systems.

The toxicity of nanoparticles is defined not only by their size, but also their form. Dendritic and spindle-shaped nanoparticles possess higher cytotoxicity as compared to spherical nanoparticles [31]. At the same time, cytotoxicity correlates with the number of facets of dendritic aluminum oxide nanoparticles [25].

The authors [32] consider that the oxide nanoparticles surface is active in the presence of numerous corners and edges. For $\mathrm{ZnO}$ concentration of superficial defects is defined by a form of nanostructures and decreases in a row: nanoplates $>$ nanosheets $>$ aggregates of nanoparticles [33]. The minimal toxic effect of the aggregates of nanoparticles is also confirmed in the study [34] where the aluminum oxide aggregated nanoparticles did not cause considerable proliferation rate suppression of the fibroblast cells (L929). Surface defects lead to redox reactions with the adsorbed water molecules. Specifically, the ion of $\mathrm{H}+$ can react with the superficial $\mathrm{H}_{2} \mathrm{O}$ molecules or $\mathrm{OH}^{-}$ forming the hydroxyl radical and superoxide radical anion $\left(\mathrm{O}_{2}{ }^{-}\right)$. These reactions cause $\mathrm{H}_{2} \mathrm{O}_{2}$ generation which induces an oxidizing stress in living cells [35].

Probably, the mechanism of $\mathrm{H}_{2} \mathrm{O}_{2}$ generation described can be realized with the aluminum oxide nanostructures of different shape exposure on normal and cancer cells inducing their viability.

While studying the effect of the nanoparticles shape and size on their toxicity, it is necessary to consider that the plasma membrane encloses the cell is a selectively permeable membrane that defines the boundary and maintains the essential intracellular environment of the cell. Important ions and nanometer-sized proteins are transported across the lipid bilayer by special protein channels [36]. The majority of other nano-dimensional macromolecules and molecular associations are internalized by the cell with endocytosis [37]. This route has been observed for gold 
nanoparticles [38], iron oxide [39-41] and fullerenes [42]. Among other factors the shape and size of the nanoparticles can be important in toxicity evaluation [43]. It is shown in [44] that the shape and size of nanoparticles are also crucial for determining their toxicity. In the study [45] significant decrease in the cell proliferation rate of the neuroblastoma cells after exposure to porous aluminum oxide particles and less effect to normal fibroblasts was shown that also demonstrates the influence of physical characteristics, such as specific surface, on nanoparticles toxicity. The surface of the nanostructured pseudoboehmite particles in antitumor effect was studied in [46]. Adsorption of the molecules and ions from the cell microenvironment on the nanostructured surface could be one of the possible mechanisms of this effect [47].

To investigate the cytotoxicity of aluminum oxide nanoparticles with different shape, we have synthesized aluminum oxide nanostructures having various morphology and their cytotoxic effect on different cancer cell lines - HeLa, A549, MDA and PyMT — has been studied.

\section{MATERIAL AND METHODS}

Aluminum nanopowder produced by electrical explosion of the aluminum wire in the argon atmosphere was used as a precursor for aluminum oxide nanostructures synthesis [48].

Agglomerates of nanosheets were produced by oxidation of the aluminum nanopowder in water at a temperature of $60^{\circ} \mathrm{C}[49]$.

Agglomerates of nanosheets were subjected to hydrothermal treatment (HTT) in autoclave with a teflon insert at a temperature of $200^{\circ} \mathrm{C}$ for six hours for synthesis of the agglomerates of nanoplates.

Cone-shaped nanoaggregates were synthesized by aluminum nanoparticles wet oxidation at a constant humidity $80 \%$ and a temperature of $60^{\circ} \mathrm{C}$.

Transmission electronic microscope JEM 2100 (JEOL, Japan) was used for the shape and size characteristics of the samples obtained. To determine the average size of the nanoparticles, particle size distribution histograms were constructed based on the data obtained from electron microscopy. The average size of the particles was calculated using Eq. (1):

$$
a_{n}=\frac{\sum n_{i} a_{i}}{\sum n_{i}}
$$

where $n_{i}$ is the number of the particles in the specified range of sizes, $a_{i}$ is the average diameter of the particles in the chosen interval.

The phase composition of the oxidation products was determined using an XRD-6000 X-ray diffractometer (Shimadzu, Japan) with $\mathrm{CuK}_{\alpha}$-radiation, $\lambda=1.78896 \AA$.

The zeta potentials were determined using a Zetasizer Nano ZSP (Malvern Instruments Ltd, UK). The specific surface and porosity were measured using thermal desorption of nitrogen on a surface area and porosity analyzer TriStar 3020 (Micromeritics, USA).

The toxicity effect of low-dimensional aluminum oxide structures was determined by MTT-test on adenocarcinomic human alveolar basal epithelial cells (A549), human cervical cancer cells (HeLa), human breast adenocarcinoma cells MDA (American Type Culture Collection) and PyMT cells (primary cells, isolated from mouse mammary tumors). The cells were added to a final concentration of $1 \times 10^{4}$ cells $/ 100 \mu 1$ per well of a 96 well microplate.

A549 and HeLa cells were cultured as monolayers in MEM supplemented with 10\% FCS, 2 mM L-Glutamine and $1 \%$ penicillin/streptomycin. MDA and PyMT cells were cultured as monolayers in DMEM supplemented with $10 \%$ FCS, 2 mM L-Glutamine and 1\% penicillin/streptomycin.

Cell lines were cultured at $37^{\circ} \mathrm{C}$ in a humidified atmosphere containing $5 \% \mathrm{CO}_{2}$ for 24 hours before adding nanoparticles. After incubation, medium was carefully removed and cells were washed twice with DPBS.

For cytotoxicity assay suspensions of nanostructures in culture media with $10 \mathrm{mg} / \mathrm{ml}, 1 \mathrm{mg} / \mathrm{ml}, 0.5 \mathrm{mg} / \mathrm{ml}$, $0.1 \mathrm{mg} / \mathrm{ml}, 0.05 \mathrm{mg} / \mathrm{ml}, 0.01 \mathrm{mg} / \mathrm{ml}$ and $0.001 \mathrm{mg} / \mathrm{ml}$ concentrations were used. Cells were incubated with nanostructures for 24 hours at $37^{\circ} \mathrm{C}$ and $5 \% \mathrm{CO}_{2}$. For MTT assay medium was carefully removed and the cells were washed twice with DPBS. After that, $100 \mu \mathrm{l}$ of culture medium and $10 \mu \mathrm{l}$ of MTT (3-4,5-dimethylthiazol-2,5 diphenyl tetrazolium bromide) were added in each well and incubated for two hours at $37 \pm 1{ }^{\circ} \mathrm{C}$ and $5 \% \mathrm{CO}_{2}$. After incubation, medium was carefully removed and formazan crystals dissolved in $100 \mu 1 /$ well of DMSO. Absorbance was measured after 15 min on a Tecan Infinite M1000 PRO (Tecan, Groding, Austria) microplate reader at $570 \mathrm{~nm}$, reference filter $690 \mathrm{~nm}$. 

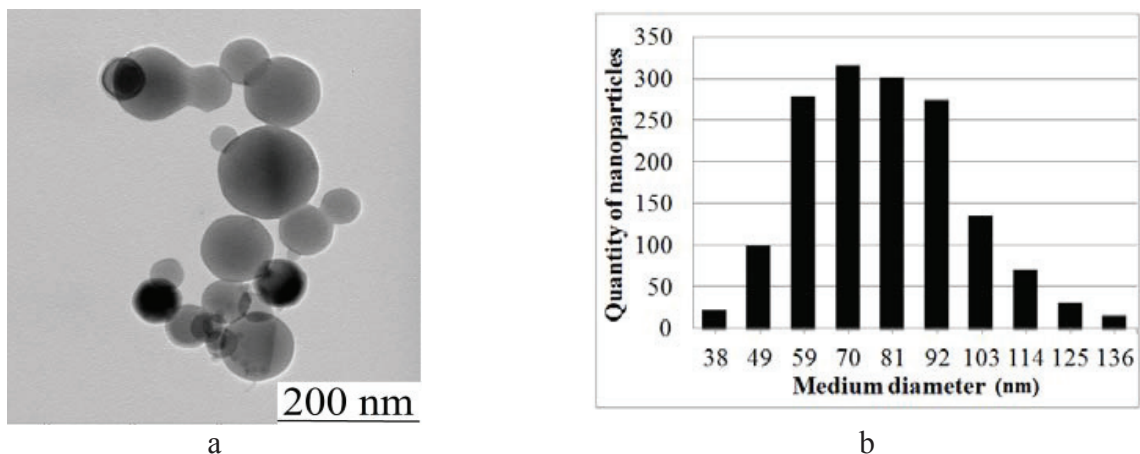

FIGURE 1. TEM-images (a) and the particle size distribution histogram (b)

All tests were performed in quadruplicate. The percentage of viable cells $\left(C_{\mathrm{L}}\right)$ was calculated using Eq. (2):

$$
C_{\mathrm{L}}=\frac{A_{\mathrm{s}}}{A_{\mathrm{c}}} \times 100 \%,
$$

where $A_{\mathrm{s}}$ is the absorbance of the sample, $A_{\mathrm{c}}$ is the absorbance of the control.

The control group was the initial culture free of contact with the low-dimensional structures. For statistical data processing, parametric methods with a significance level of $p \leq 0.05$ were used.

\section{RESULTS AND DISCUSSION}

The aluminum nanoparticles which are precursors for the aluminum oxide nanostructures synthesis have spherical shape (Fig. 1a). The particle size distribution histogram presented on Fig. 1b. The average size of aluminum nanoparticles obtained is $78 \mathrm{~nm}$.

Agglomerates of nanosheets as porous structures are formed after water oxidation of aluminum nanopowder (Fig. 2a, d). Such morphology is formed due to high reaction speed and reagent excess at a temperature of $60^{\circ} \mathrm{C}$. The size of agglomerates is in the range of $0.5-2.0 \mu \mathrm{m}$. Agglomerates of nanosheets have many edges formed by separate nanosheets with planar size of about $100 \mathrm{~nm}$ and $2-5 \mathrm{~nm}$ thick (Fig. 2d).
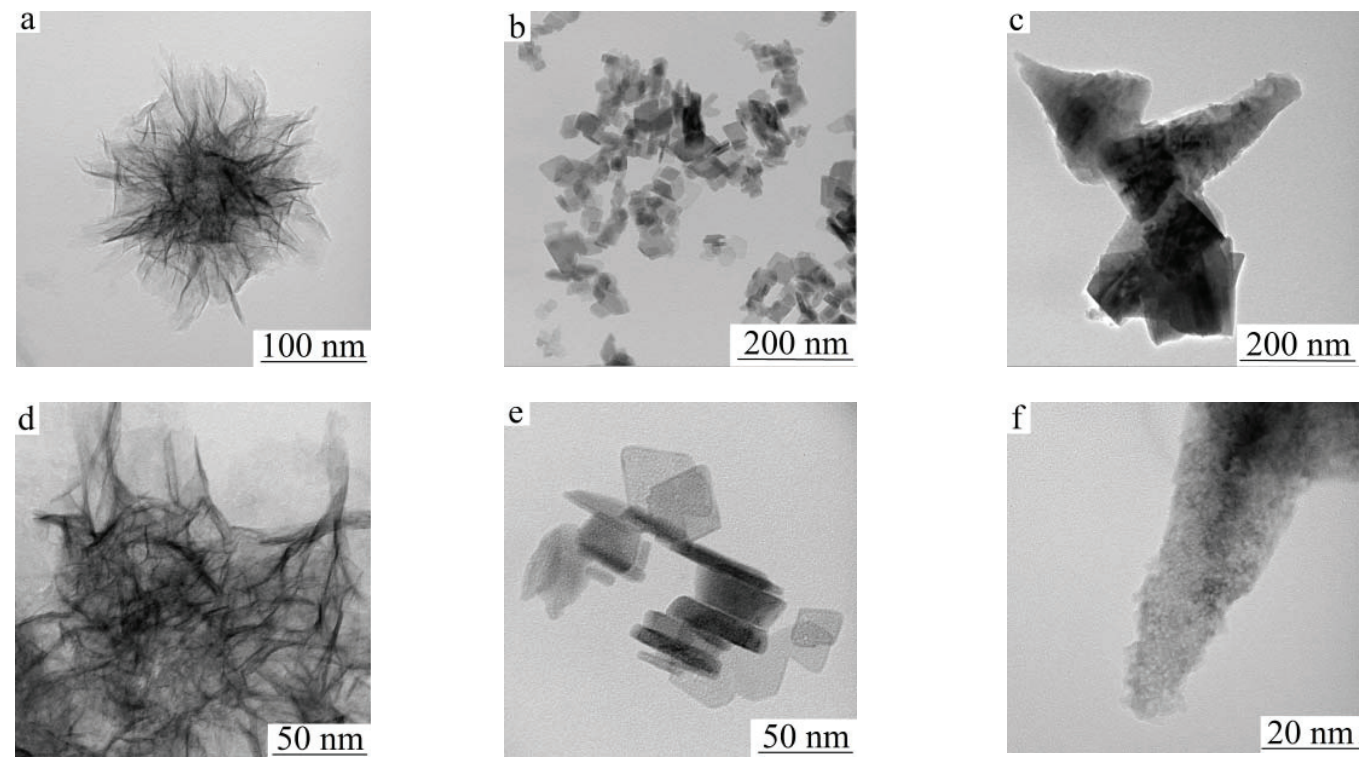

FIGURE 2. TEM of particles obtained by oxidation in water (a, d), in water plus HTT (b, e), and in humid air (c, f) 


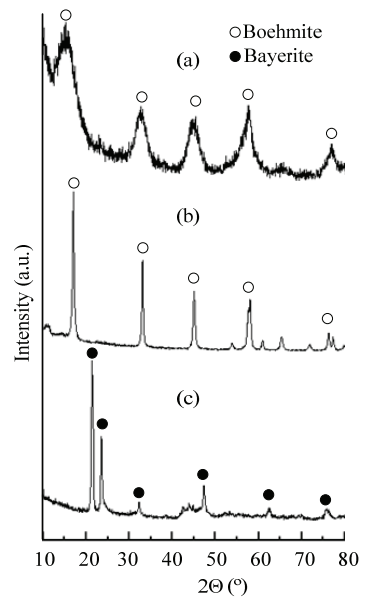

FIGURE 3. X-ray diffraction analysis of the samples produced during aluminum nanopowder water oxidation (a), after hydrothermal treatment (b) and wet air oxidation (c)

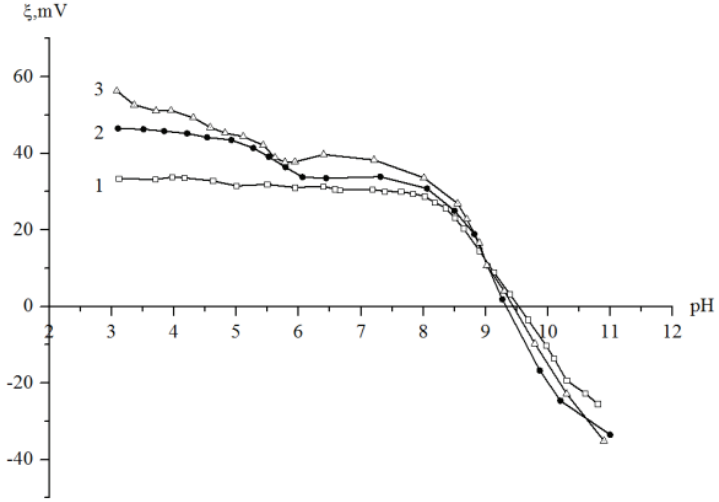

FIGURE 4. Dependence of zeta-potential from $\mathrm{pH}$ : 1 -agglomerates of pseudoboehmite nanosheets, 2nanoplates of boehmite, 3 - cone-shaped nanoaggregates

After the hydrothermal treatment of agglomerates of nanosheets faceted lamellar nanostructures are formed (Fig. 2b, e). This change of morphology is connected with the accelerated aging processes caused, mainly by the higher steam pressure. Nanoplates have the planar size of 20-100 nm and 4-15 nm thick (Fig. 2e).

Oxidation of the aluminum in the wet air leads to formation of cone-shaped nanoaggregates with the characteristic size of 100-300 nm (Fig. 2c). Nanoaggregates are formed with separate aluminum oxide nanoparticles of 2-5 nm in size (Fig. 2f). The formation of this morphology is connected with reduction of the speed reaction compared to oxidation with water, due to the lack of reagent and slow water delivery to nanoparticles surface.

Figure 3 presents the diffraction patterns of the aluminum nanoparticle water and wet air oxidation products. Pseudoboehmite is the product of the aluminum oxidation with water (Fig. 3a). The main peaks correspond to a crystal boehmite phase (PDF No 00-005-0190). Crystal boehmite phase is the product of agglomerates of nanosheets hydrothermal treatment (PDF No 01-074-2901) (Fig. 3b). Bayerite is formed in the wet air (PDF No 00-012-0457) (Fig. 3c). In all cases, we have the complete oxidation of metal aluminum. The line broadening on the pseudoboehmite diffraction pattern (Fig. 3a) whose relative arrangement is similar to the most intensive lines of the boehmite (Fig. 3b) can be caused by the following: small area sizes of the coherent dispersion $(\leq 1000 \AA)$; the presence of micro-tension arising in a crystal lattice of a separate crystal and the interlayer water availability.

Textural characteristics research has shown that the specific surface of the agglomerates of nanosheets was $265 \mathrm{~m}^{2} / \mathrm{g}$, nanoplates $-198 \mathrm{~m}^{2} / \mathrm{g}$, cone-shaped nanoaggregates $-12 \mathrm{~m}^{2} / \mathrm{g}$.

By zeta potential dependence on $\mathrm{pH}$ investigation (Fig. 4) with potentiometric titration it is established that all synthesized nanostructures possess positive zeta-potential in the range from $\mathrm{pH} 3$ to 9 , and have similar point of zero charge $\left(\mathrm{pH}_{\mathrm{pzc}}\right)$ value: $\mathrm{pH}_{\mathrm{pzc}}=9.53$ for agglomerates of nanosheets; $\mathrm{pH}_{\mathrm{pzc}}=9.32$ for nanosheets; $\mathrm{pH}_{\mathrm{pzc}}=9.43$ for cone-shaped nanoaggregates.

Thus, all synthesized samples have the positive surface charge, $\mathrm{pH}_{\mathrm{pzc}}$ value is about 9.5. It is possible to assume that the positive charge of aluminum oxide nanostructures (as opposed to the cells charge) can increase their bioactivity due to electrostatic forces.

\section{ANTITUMOR ACTIVITY STUDY}

The synthesized nanostructures have a quite big size that do not allow them to be taken up by the cells [50, 51], and their toxic effect will depend mostly on the shape and surface properties (acid-base properties, the charge, presence of impurities, etc.).

As can be seen in Fig. 5a the lowest toxic effect on the HeLa cell line was observed for nanoaggregates and nanoplates at all investigated concentrations.

Nanoplates and nanoaggregates had also a low toxic effect on PyMT cell line (Fig. 5b). The amount of living cells did not depend on the aluminum oxide nanostructures concentration. 

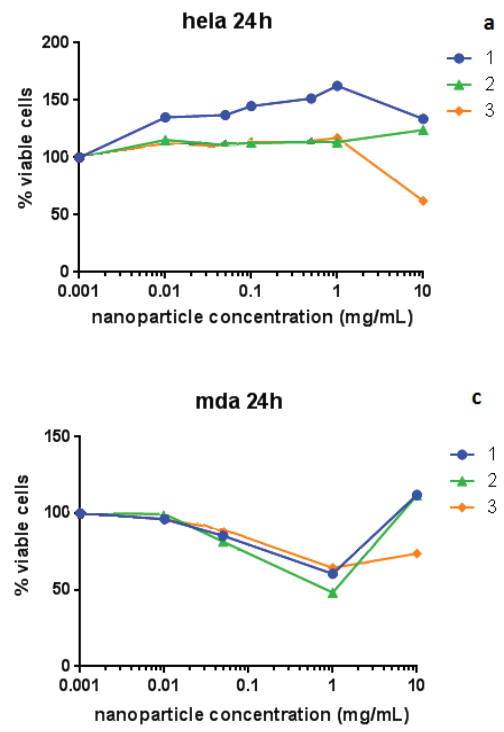
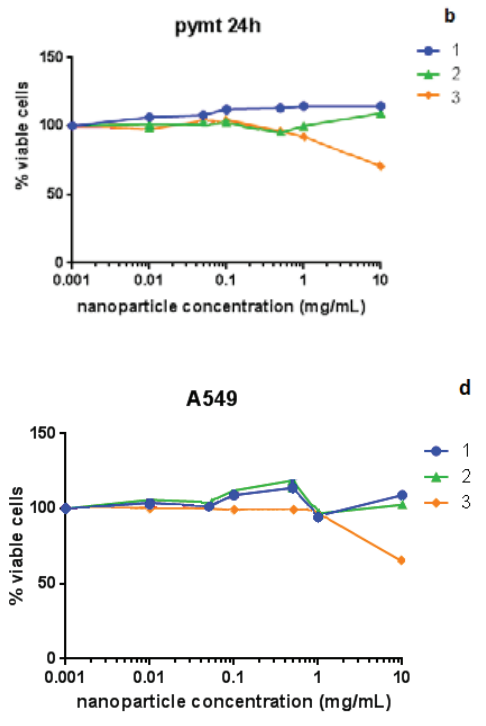

FIGURE 5. Aluminum oxide low-dimensional structures effect on A549 cells (a), HeLa cells (b), MDA cells (c), PyMT cells (d): 1 -nanoplates, 2 - cone-shaped nanoaggregates, 3 -agglomerates of nanosheets

The synthesized nanostructures had a toxic effect on MDA cell line (Fig. 5c). Decrease in viable cells from 20 to $30 \%$, in the range of nanostructure concentrations from 0.001 to $1 \mathrm{mg} / \mathrm{ml}$ was observed. The toxic effect was significantly reduced at $10 \mathrm{mg} / \mathrm{ml}$ of samples concentration. It could be the result of the redox reactions inducing the oxidative stress in the living cells [52] which activates oxidant-sensitive transcription factors, which in turn results in the resistance of the tumor cells to oxidants [53, 54].

A low toxic effect of the nanoplates and nanoaggregates on A549 cell line (Fig. 5d) was revealed in the whole concentration range.

Agglomerates of nanosheets, as compared to other synthesized nanostructures, had toxic effect for all cell lines in the range of concentrations from 1 to $10 \mathrm{mg} / \mathrm{ml}$ (Figs. 5a-5d).

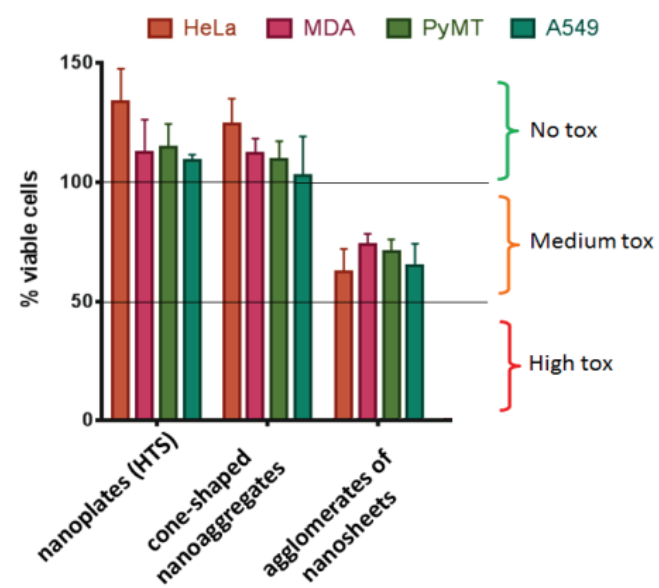

FIGURE 6. Cell viability (24 hours, $10 \mathrm{mg} / \mathrm{ml}$ ) 
Figure 6 presents the histograms demonstrating the toxic action of the synthesized nanostructures at a concentration of $10 \mathrm{mg} / \mathrm{ml}$. As follows from the figure, nanoplates and cone-shaped nanoaggregates are nontoxic to the cell lines investigated. Agglomerates of nanosheets show the highest toxic effect, but do not suppress cell viability completely and could be defined as medium toxic to the above-mentioned cell lines.

Agglomerates of nanosheets, due to many facets, have a large number of surface defects, as compared to other nanostructures. Possibly, there is a generation of superoxide radicals, hydrogen peroxide and hydroxyl radicals take place, which are crucial for inducing toxicity [49].

\section{CONCLUSION}

Based on aluminum oxide phases, positively charged low-dimensional structures with different morphology were synthesized with water oxidation method. Agglomerates of the pseudoboehmite nanosheets are formed in reaction of aluminum with water. After pesudoboehmite hydrothermal treatment, the faceted lamellar structures of a crystal boehmit are formed. Wet air oxidation of aluminum leads to the formation of the cone-shaped nanoaggregates. The synthesized nanostructures have a positive surface charge and differ by the number of facets.

The data obtained show that the antitumor activity of nanomaterials based on aluminum hydroxides along with other factors is defined by their shape, mainly the number of edges and facets of nanostructures. Toxicity study of the synthesized nanostructures on cancer cell lines A549, HeLa, MDA and PyMT have shown that increasing number of nanostructure edges enhance toxic effect. Nanoplates and cone-shaped nanoaggregates are non-toxic, the agglomerates of nanosheets having multiple edges and folds in the range of concentration from 1 to $10 \mathrm{mg} / \mathrm{ml} \mathrm{have} \mathrm{a}$ medium toxic effect that confirms earlier data $[45,34]$ about the influence of the shape and size on the toxicity of the nanoparticles having a big specific surface.

These data support the mechanism of cell viability suppression which was offered earlier in the literature due to the active centers forming on surface defects of nanostructures. Further study of the mechanisms which are the basis of the nanoparticles interaction with cells will help create new concepts for cancer disease treatment.

\section{ACKNOWLEDGMENTS}

This work was supported by the Russian Science Foundation (Grant No. 14-23-00096). Nanoparticles were produced within the frames of the Fundamental Research Program of the State Academies of Sciences for 20132020. Electron microscopy and X-ray structural studies were performed using the equipment of the Nanotech CUC of the ISPMS SB RAS. The authors are grateful to Andreja Bratovs from the Josef Stefan Institute (Slovenia) for her guidance in cell studies.

The study reported in this article was conducted according to accepted ethical guidelines involving research in humans and/or animals and was approved by an appropriate institution or national research organization.

The study is compliant with the ethical standards as currently outlined in the Declaration of Helsinki.

All individual participants discussed in this study, or for whom any identifying information or image has been presented, have freely given their informed written consent for such information and/or image to be included in the published article.

\section{REFERENCES}

1. G. Mikhaylov, D. Klimpel, N. Schaschke, U. Mikac, M. Vizovisek, M. Fonovic, V. Turk, B. Turk, and O. Vasiljeva, Angew. Chem. Int. Ed. 53(38), 10077-10081 (2014).

2. G. Mikhaylov, U. Mikac, A. A. Magaeva, V. I. Itin, E. P. Naiden, I. Psakhye, and M. Bogyo, Nature nanotechnology 6(9), 594-602 (2011).

3. N. L. Rosi and C.A. Mirkin, Chem. Rev. 105, 1547-1562 (2005).

4. A. Lozhkomoev, E. Glazkova, E. Khorobraya, M. Lerner, A. Maltsev, and V. Podkovyrov, Rus. Phys. J. 56(4), 384-388 (2013).

5. N. Lewinski, V. Colvin, and R. Drezek, Small 4, 26-49 (2008).

6. W. H. De Jong and P. J. Borm, Int. J. Nanomedicine 3, 133-149 (2008).

7. O. V. Bakina, N. V. Svarovskaya, E. A. Glazkova, A. S. Lozhkomoev, E. G. Khorobraya, and M. I. Lerner, Adv. Powder Technol. 26(6), 1512-1519 (2015). 
8. O. V. Bakina, E. A. Glazkova, N. V. Svarovskaya, A. S. Lozhkomoev, E. G. Khorobraya, and S. G. Psakhie, AIP Conf. Proc. 1623, 35 (2014).

9. S. G. Psakhie, K. P. Zolnikov, D. S. Kryzhevich, A. V. Abdrashitov, and M. I. Lerner, Phys. Mesomech. 13(3), 184-188 (2010).

10. A. Sossi, E. Duranti, C. Paravan, L. T. DeLuca, A. B. Vorozhtsov, A. A. Gromov, Y. I. Pautova, M. I. Lerner, and N. G. Rodkevich, Appl. Surf. Sci. 271, 337-343 (2013).

11. A. S. Lozhkomoev, E. A. Glazkova, N. V. Svarovskaya, O. V. Bakina, S. O. Kazantsev, and M. I. Lerner, AIP Conf. Proc. 1683, 020128 (2015).

12. A. S. Lozhkomoev, E. A. Glazkova, N. V. Svarovskaya, O. V. Bakina, S. O. Kazantsev, and M. I. Lerner, AIP Conf. Proc. 1683, 020127 (2015).

13. A. S. Lozhkomoev, E. A. Glazkova, S. O. Kazantsev, I. A. Gorbikov, O. V. Bakina, N. V. Svarovskaya, and S. G. Psakhie, Nanotechnologies Rus. 10(11-12), 858-864 (2015).

14. A. S. Lozhkomoev, E. A. Glazkova, O. V. Bakina, M. I. Lerner, I. Gotman, E. Y. Gutmanas, S. O. Kazantsev, and S. G. Psakhie, Nanotechnology 27(20), 205603-205609 (2016).

15. S. Singh, T. Shi, R. Duffin, C. Albrecht, D. van Berlo, D. Hohr, B. Fubini, F. Martra, I. Fenoglio, P. J. Borm, and R.P. Schins, Toxicol. Appl. Pharmacol. 222, 141-151 (2007).

16. M. I. Lerner, A. V. Pervikov, E. A. Glazkova, N. V. Svarovskaya, A. S. Lozhkomoev, and S. G. Psakhie, Powder Technology 288, 371-378 (2016).

17. N. V. Svarovskaya, A. V. Berenda, O. V. Bakina, E. A. Glazkova, A. S. Lozhkomoev, E. G. Khorobraya, V. V. Domashenko, M. I. Lerner, and A. N. Fomenko, Progr. Nat. Sci. Mater. Int. 25(1), 1-5 (2015).

18. K. Xuebin, H. Yiming, T. R. Dargaville, F. Yiqun, C. Zhanfeng, and Z. Huaiyong, Separation Purification Technology 120, 239-244 (2013).

19. M. Pailleux, D. Boudard, J. Pourchez, V. Forest, P. Grosseau, and M. Cottier, Toxicology in Vitro 27, 1049$1056(2013)$

20. A. J. Wagner, C. A. Bleckmann, R. C. Murdock, A. M. Schrand, J. J. Schlager, and S. M. Hussain, Phys. Chem. B 111, 7353 (2007).

21. E. Radziun, W. J. Dudkiewicz, I. Książek, K. Nowak, E. L. Anuszewska, A. Kunicki, A. Olszyna, T. Ząbkowski, Toxicol In Vitro 25(8), 1694-1700 (2011).

22. A Simon-Deckers, B. Gouget, M. Mayne-L'Hermite, N. Herlin-Boime, C. Reynaud, and M. Carrie`re, Toxicology 253, 137-146 (2008).

23. X. Q. Zhang, L. H. Yin, M. Tang, and Y. P. Pu, Biomed. Environ. Sci. 24(6), 661-669 (2011).

24. I. S. Kim, M. Baek, S. J. Choi, J. Nanosci. Nanotechnol. 10(5), 3453-3458 (2010).

25. L. Weisheng, S. Isaac, H. Yue-wern, Z. Xiao-Dong, and M. Yinfa, Toxicological Environmental Chemistry 90, 983-996 (2008).

26. A. Yamamoto, R. Honma, M. Sumita, and T. Hanawa, J. Biomed. Mater. Res. 68, 244 (2008).

27. F. Arul Prakash, G. J. Dushendra Babu, M. Lavanya, K. S. Vidhya, and T. Devasena, Int. J. Nanotechnol. Appl. 5, 99-107 (2011).

28. L. Chen, R. Yokel, B. Hennig, and M. Toborek, J. Neuroimm. Pharmacol. 3(4), 286-295 (2008).

29. M. R. Wilson, J. H. Lightbody, K. Donaldson, J. Sales, and V. Stone, Toxicol. Appl. Pharmacol. 184, 175 (2002).

30. Q. L. Zhang, M. Q. Li, J. W. Ji, F. P. Gao, R. Bai, C. Y. Chen, Z. W. Wang, C. Zhang, and Q. Niu, Int. J. Immunopathol. Pharmacol. 24(Suppl. 1), 23S-29S (2011).

31. J. Wang, G. Zhou, C. Chen, H. Yu, T. Wang, Y. Ma, G. Jia, Y. Gao, B. Li, J. Sun, Y. Li, F. Jiao, Y. Zhao, and Z. Chai Toxicol. Lett. 168(2), 176-185 (2007).

32. P. K. Stoimenov, R. L. Klinger, G. L. Marchin, and K. J. Klabunde, Langmuir, 18, 6679-6686 (2002).

33. M. Ramani, S. Ponnusamya, C. Muthamizhchelvan, and E. Marsili, Colloids Surfaces B Biointerfaces 117, 233-239 (2014).

34. A. N. Fomenko, M. S. Korovin, O. V. Bakina, S. O. Kazantsev, E. A. Glazkova, N. V. Svarovskaya, A. S. Lozhkomoev, AIP Conf. Proc. 1683, 020054 (2015).

35. N. Padmavathy and R. Vijayaraghavan, Sci. Technol. Adv. Mater. 9, 035004 (2008).

36. A. J. B. Alberts, J. Lewis, M. Raff, K. Roberts, and P. Walter, Molecular Biology of the Cell (Garland Science, Taylor and Francis Group, New York, 2002).

37. S. D. Conner, S. L. Schmid, Nature 422, 37-44 (2003).

38. R. Shukla, V. Bansal, M. Chaudhary, A. Basu, R. R. Bhonde, and M. Sastry, Langmuir 21, 10644 (2005)

39. Y. J. Ma and H. C. Gu, J. Mater. Sci. Mater. Med. 18, 2145 (2007). 
40. P. Pradhan, J. Giri, R. Banerjee, J. Bellare, and D. Bahadur, J. Magn. Magn. Mater. 311, 282-287 (2007).

41. G. F. Goya, I. Marcos-Campos, R. Fernandez-Pacheco, B. Saez, J. Godino, L. Asin, J. Lambea, P. Tabuenca, J. I. Mayordomo, L. Larrad, M. R. Ibarra, and A. Tres, Cell Biol. Int. 32, 1001 (2008).

42. W. Li, C. Y. Chen, C. Ye, T. T. Wei, Y. L. Zhao, F. Lao, Z. Chen, H. Meng, Y. X. Gao, H. Yuan, G. M. Xing, F. Zhao, Z. F. Chai, X. J. Zhang, F. Y. Yang, D. Han, X. H. Tang, and Y. G. Zhang, Nanotechnology 19, 12 (2008).

43. B. D. Chithrani and W. C. W. Chan, Nano Lett. 7, 1542 (2007); Nano Lett. 6, 662 (2006).

44. A. E. Nel, L. Madler, D. Velegol, T. Xia, E. M. V. Hoek, P. Somasundaran, F. Klaessig, V. Castranova, and M. Thompson, Nat. Mater. 8, 54 (2009).

45. S. O. Kazantsev, A. N. Fomenko, M. S. Korovin, E. A. Glazkova, A. S. Lozhkomoev, M. I. Lerner, and S. G. Psakhie, AIP Conf. Proc. 1683, 020080 (2015).

46. A. S. Lozhkomoev, M. I. Lerner, A. A. Tsukanov, S. O. Kazantsev, O. V. Bakina, and S. G. Psakhie, Phys. Mesomech. 20 (2017).

47. A. A. Tsukanov and S. G. Psakhie, Sci. Rep. 6, 19986 (2016).

48. M. I. Lerner, E. A. Glazkova, A. S. Lozhkomoev, N. V. Svarovskaya, O. V. Bakina, A. V. Pervikov, and S. G. Psakhie, Powder Technology 295, 307-314 (2016).

49. A. S. Lozhkomoev, E. A. Glazkova, O. V. Bakina, M. I. Lerner, I. Gotman, E. Y. Gutmanas, S. O. Kazantsev, and S. G. Psakhie, Nanotechnology 27(20), 205603-205609 (2016).

50. S. Zhang, J. Li, G. Lykotrafitis, G. Bao, and S. Suresh, Adv. Mater. 21, 419-424 (2009).

51. W. Jiang, B. Kim, J. Rutka, and W. Chan, Nature Nanotech. 3, 145-150 (2008).

52. S. Alarifi, D. Ali, and S. Alkahtani, Int. J. Nanomedicine 10, 3751-3760 (2015).

53. G. Pani, T. Galeotti, and P. Chiarugi. Cancer Metastasis Rev. 29(2), 351-378 (2010).

54. R. A. Gatenby and R. J. Gillies. Nat. Rev. Cancer 4(11), 891-899 (2004). 